\title{
People, Ideas, Culture in Shaping the Shared Value Society
}

\author{
Kenneth Wong See Huat \\ Founder, PIC Consultancy, Kuala Lumpur, Malaysia \\ peopleideasculture@gmail.com
}

\begin{abstract}
In March 2017, the open call of artists in participate the LOCK UP locker art exhibition has been realized, whereby ten artists have created 24 artworks that can fit only into the compartment size of the two locker cabinets. This happened in collaboration with Harry Rogers Home furniture outlet and was touching on the issues of prisonary, corruption and LGBTQ in the closet. The success lead to the further prompt in curatorial work for the International Mother Earth Day: "Owls Know" Photography Exhibition and "Sea of Tears" group painting exhibition that gathered Singaporean, Malaysian, Philippino and Indonesian artists in pondering the issue of piracy and paperless children along Melacca Straits, South China Sea and Sulu Sea. To sum up, the survival of People Ideas Culture as social enterprise is based on the principal of "Shared Value, Shared Space" that allows the venue sponsorship to kick off most of the events, and using the art as tool to reach out the public who seems to be ignorant and apathetic via a subtle approach.
\end{abstract}

Keywords bottom up governance, social artistry, social enterprise, place making, cultural programming

\section{Introduction}

The establishment of People Ideas Culture 人思文 as social enterprise is an outcome after losing faith on public policy after the airing of the incident "State of Fear: Murder and Money in Malaysia" 1 . This entity is advocating the bottom up governance and active citizenship, which it believes that to shape the value of a society, it shall start at individual capacity. Money laundry is not just happened overnight but as an inconvenient truth conduct locally and regionally over the decades.

This entity focuses on cultural programming and place making as core business lines. Cultural programming in general term is like art programming. It provides curatorial consultancy for organizing art and cultural activity, but in a deeper meaning, it refers to social reengineering. Whereas the place making is more incline towards revitalizing the underutilized public spaces in town.

\section{Bangsar Heritage Walk}

Since its set up in March 2016, the very first oral history project has initiated in Bangsar. The contact for interviewing the senior citizens was established via the residence associations in Bangsar. The collective memory and archival information researched on, has turned into three walks: Bangsarian His-story Walk (May 2016), Bangsar Trademark Walk (July 2016) and Bangsar Place Making Walk (October 2016). These three walks has different emphasize in depicting the hidden gems in Bangsar that is currently facing the pressure of redevelopment. These projects have parked under a web platform called Lokalocal.com as a community guide for local market as well as tourist in promoting city heritage 2.

Bangsarian His-story Walk showcases some of the significant historical landmarks of Bangsar: from a rubber estate and how it evolved into an affluent neighborhood and hipster pub area in Klang Valley. The walk is along Jalan Bangsar whereby in olden days it was just an earthy road 
with bull cart and end up at TNB (Central Electricity Board). Bangsar Trademark Walk as second walk that brings one to the old business premises that have run more than 20 years in Bangsar, be it grocery shop, hardware shop, barber shop, pub, kopitian etc. It is not easy to sustain that long in Bangsar as the new ventures who come in usually don't last more than three years in the neighborhood due to rocket high rental. The third one, Bangsar Place Making Walk means to showcase what could urban intervention and initiative from the local stakeholders could play in further enhancing the vitality of the neighborhood. This walk is more inclined towards those who appreciate the architecture, landscape and urban regeneration topics. This walk is incubated after winning the first prize in a place making workshop organized by YPLab (Young Professional Lab) under the wing of Malaysia Institute of Architects.

\section{3. "Overhead Bridge Festival"}

As both an overarching idea and a hands-on approach for improving a neighborhood, city, or region, place making inspires people to collectively re-imagine and reinvent public spaces as the heart of every community. Strengthening the connection between people and the places they share, place making refers to a collaborative process by which we can shape our public realm in order to maximize shared value. More than just promoting better urban design, place making facilitates creative patterns of use, paying particular attention to the physical, cultural, and social identities that define a place and support its ongoing evolution.

Subsequently, an "Overhead Bridge Festival" was purposed with the theme "Silver Lining" in December 2016 against the national uncertainty after Bersih mass rally and depletion of Ringgit Malaysia 3. The objectives of this art market are: (i) Bridging The Urban Poor (Abdullah Hukum) and the Rich (ii) Make Art Accessible to Public (iii) Enhance the Sense of Belonging. However, the art market that was supposed to take place on the overhead bridge didn't get the permit from the local authority due to the lame excuses: obstacle in public space, safety concern and traffic jam. A petition has put online for appealing.

\section{Talks in Cafes and Bazaar}

People Ideas Culture observed that lots of public discourses are refrained at conference, dialog, roundtable which usually take place in conference rooms and galleries which are very much limited to intellectual crowd and elite community. Hence various talks have also been organized, but inside cafe settings. These are the usual place where the general public loves to gather for chit chat and socialize. Among the talks are :"Invisibility/Invincibility" on the mapping possibility of LGBTQ space in Klang Valley; "To
Share/Not to Share" on the sharing economy and "Shared Value, Shared Space" in promoting the coexistence of old and new. One bazaar has been held with talks on "Future Cities" and "The Power of Design", which integrated the parents, architects, bazaar vendors that hardly come across their path in public discourse avenue. In February 2017, the collective cultural mapping project has taken place in "The Ruang" with a panel exhibition and talks that consisted of various individuals active in mapping the cities in various perspectives, be it map production, literature tracing, heritage walks and street photography. Bangsar Heritage Walk project has been shared over a short film screening, a panelist discussion and a guided walk.

\section{Art Exhibition in Non-Gallery Setting}

In March 2017, the open call of artists in participating the "LOCK UP" locker art exhibition has been realized, whereby ten artists have created 24 artworks that can fit only into the compartment size of the two locker cabinets. This happened in collaboration with Harry Rogers Home furniture outlet and was touching on the issues of prisonary, corruption and LGBTQ in the closet. The success lead to the further prompt in curatorial work for the International Mother Earth Day: "Owls Know" Photography Exhibition and "Sea of Tears" group painting exhibition. The "Owls Know" Photography Exhibition (with a Mauritius photographer) took place in a café in Old Klang Road with pots of little greenery plants. The "Sea of Tears" regional exhibition gathers Singaporean, Malaysian, Philippino and Indonesian artists in pondering the issue of piracy and paperless children along Melacca Straits, South China Sea and Sulu Sea. Even though this exhibition was held in a commercial gallery (due to the shipping cost and framing cost were absorbed by the gallery), one short film screening on Bajau community and one panelist discussion on human trafficking via sea-route have successfully drawn a non-gallery crowd to the new avenue. This is what People Ideas Culture relentlessly championing for: in breaking the barrier that art is only accessible for the privileged. Another unusual exhibition has been held in a vegan café, located inside a property showroom, whereby the artists were using the antique typewriter as medium for creating the artworks that are related to the theme "Reviving the Past, Connecting the Future". This innovative way of curatorship has disrupted the norm that exhibition only take places in gallery and usually by invitation for opening kind.

\section{Achievements and Results}

The events of People Ideas Culture have been featured by various media, be it printed media4, online social media and TV channels. Discovery Travel Agency has an eye to the Bangsar Heritage Walks project and has it promoted in in- 
ternational tourism fairs as niche product in March 2017. The fact of being invited to put up the collective exhibition of "KOTA PETA" in Feb 2017 is a gesture from the peers of advocacy and like- minded NGO recognizing the effort of People Ideas Culture. The talk "Shared Value, Shared Space" is also invited for a discussion in a Buddhism bookstore. The abstract of "Social Enterprise as New Approach in Revitalizing the Urban Heritage" has been well accepted by International Cultural Tourism Committee. As founder, I have been invited on air with Ai Fm and TV2 Frontier Window program for my Bangsar Heritage Walk initiative5.

The "LOCK UP" locker art exhibition was well received during the opening and the artists and myself have been invited by radio program bfm "The Bigger Picture" 6 . The "Sea of Tears" exhibition has been well echoed with a panelist talk with NGO named "Tenaganita" touching on the human trafficking issues via sea routes. An in-depth interview with the trafficked victim has been covered by online media, Free The Malaysia (FTM) 7. Both exhibitions mentioned have received positive art critics online on Aquacultblog8 and Artmalaysiagroup9.

Most of the curated art exhibitions and talks got the venue sponsorships due to the value of the proposed project and the win-win situation that People Ideas Culture has created for the business owners who were keen to partake in the same project direction. PIC has also succeeded in raising three refreshment beverage sponsorships so far: Anggun boutique hotel, The Basikal and Art Coffee. Founder has also been engaged by Pure Space in Klang to share his scholar experience in both Hong Kong and Europe with ADB scholarship and Erasmus Mundus scholarship.

\section{Challenges and Discussion}

This social enterprise emerged in recognizing the limitation of "Think City" (funded by Khazanah) that targeted the urban regeneration issues in city centres (Georgetown, Kuala Lumpur and Johor Bahru). As personal experience dealing with local council for "Overhead Bridge Festival" which was supposed to take place in Dec 2016, the bureaucracy and under table money is an inconvenient truth. The proposal has been declined with lame excuses: obstacles in public space, safety and traffic jam concern.

The "Overhead Bridge Festival" mentioned earlier aims in bringing the art closer to the residents and workers in Abdullah Hukum with 16 booths. Such kind of art market is a norm even in Yangon, Shanghai and Taipei. The proposed opening hour were late noon during the weekend to avoid the public crowd during weekdays. Further, there are two huge car parks available at Jalan Riong. Hence, one recognizes the red tapes in dealing with local council, even for the second initiatives in Jalan Tengah (no single respond and call at all for meeting since proposal delivered in hardcopy after two months the petition online about the overhead bridge festival).

Another example regards the state government is the proposal in revitalizing the tin mining dredging machine in Tanjung Tualang, Perak. Four doors have been knocked and meetings have been conducted one after another: from Institut Darul Ridzuan, Amanjaya Corp, Unit Perancangan Ekonomi Perak till Tourism Perak. The real positive confirmation only happened in April 2017 since first approach in June 2016. Hence, it seems lengthy, exhausting and not productive in dealing with government, not to mention the tricky parts, be it nepotism or cronyism.

Lastly, it is still the mentality of Malaysian local market that is less supportive to local art and cultural products compared to the ecosystem in Singapore, Taipei, Yogyakarta and Bangkok. Despite the fact, thatmost Malaysians are willing to spend for similar art and cultural consumption when they travel to the cities mentioned in the region. This is the problem what People Ideas Culture is trying to address. From there, we push to promote bottom up governance, active citizenship and make art accessible to all, in order to mobilize the grassroots for civic awareness agenda.

\section{Conclusion}

To sum up, various projects undertaken by People Ideas Culture 人思文 10 have showed how the social reengineering could take place without hardcore political action but with subtle social artistry approach which is wittily dealing with people, ideas and culture. The sustainability of People Ideas Culture is also based on the principle of "Shared Value, Shared Space" which allows the venue sponsorship to kick off most of the events, and using the art as tool to reach out the public for the betterment of the society.

\section{ACKNOWLEDGEMENT}

People Ideas Culture would like to express the deepest gratitude to the interviewees, angel investor, mentors, sponsors and volunteers in various projects since its establishment.

\section{REFERENCES}

[1] State of Fear Murder and Money in Malaysia, [Online]. Available: https://www.youtube.com/watch?v=YlAqyw8RVeU, reported by Linton Besser, Jaya Balendra, Elise Worthington- ABC 
[2] Lokalocal community guide page, [Online]. Available: https://lokalocal.com/profile/7

[3] Malaysia's ringgit may keep tumbling amid the market's Trump tantrum, [Online]. Available: http://www.cnbc.com/2016/11/21/why-malaysias-ringgit-ma y-keep-tumbling-amid-the-markets-trump-tantrum.html, reported by Leslie Shaffer, CNBC.

[4] Feature Coverage on Redevelopment Concern in Bangsar, [Online].

Available:

http://www.sinchew.com.my/node/1581909/\%E6\%96\%B0\% E6\%97\%A7\%E5\%AD\%9F\%E6\%B2\%99\%E5\%90\%91\%E5 \%89\%8D\%E7\%9C\%8B\%EF\%BC\%88\%E4\%B8\%89\%E4\% B9\%8B\%E4\%B8\%80\% EF\%BC\%89\%C2\%B7\%E5\%AD\%9 F\%E6\%B2\%99\%E5\%8D\%8E\%E4\%B8\%BD\%E8\%BA\%A B\%E5\%BD\%B1\%E4\%B8\%8B\%E7\%9A\%84\%E5\%BA\%B 6\%E6\%B0\%91\%E9\%A3\%8E\%E6\%83\%85, Sin Chew Daily dated 1 Nov 2016.

[5] Frontier Window coverage on Bangsar Heritage Walk, [Online]. Available: https://www.facebook.com/114544091918888/videos/14532 08004719150/, TV2.

[6] LOCK UP Locker Art, [Online]. Available: http://www.bfm.my/locker-art-kenneth-wong-linda-liao-ana hita-ganzafari, BFM89.9, "The Bigger Picture".

[7] Bangladeshi relives horror as a trafficked person, [Online]. Available:

http://www.freemalaysiatoday.com/category/nation/2017/05/ 22/bangladeshi-relives-horror-as-a-trafficked-person/, reported by Leslie Shaffer, FMT News.

[8] Unlock That Art, [Online]. Available: https://aquacultblog.wordpress.com/2017/03/13/unlock-thatart/, art critics by Sona Ghose.

[9] SEA OF TEARS EXHIBITION L'ATELIER ROUGE, [Online]. Available: http://artmalaysiagroup.com/arttalk/detail/136/sea-of-tears-e xhibition-1\%E2\%80\%99atelier-rouge, art critics by Jane Khoo

[10] People Ideas Culture 人思文 social enterprise page, https://www.facebook.com/People-Ideas-Culture-\%E4\%BA \%BA\%E6\%80\%9D\%E6\%96\%87-596103760542966/ 